\title{
Meet the 2020 Bunche Fellows
}

$\mathrm{T}$ he APSA Ralph Bunche Summer Institute (RBSI) is an annual fiveweek program, held at Duke University, under the direction of current APSA president Dr. Paula D. McClain. RBSI is designed to introduce undergraduate students from underrepresented racial and ethnic groups to the world of graduate study and to encourage application to political science $\mathrm{PhD}$ programs. Due to circumstances and concerns related to COVID-19, Duke University officials canceled the university's summer session during which the RBSI program would have been held. Therefore the 2020 RBSI program was also canceled. APSA is in the process of developing a slate of possible alternative professional development, mentoring, and research opportunities for the 2020 Bunche Fellows to participate in.

\section{Kennedy Anderson}

Kennedy Anderson is a junior honor student attending Converse College. She is majoring in politics with a minor in dance.

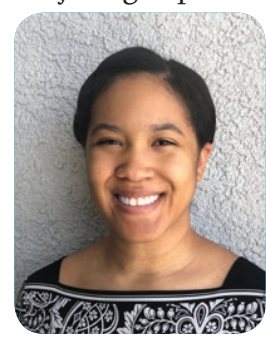
Kennedy is involved on campus, currently serving as Student Government President and a member of multiple honor societies including Alpha Lambda Delta, Mortar Board, and Omicron Delta Kappa. Kennedy also participates in Model Programs, competing in Model NATO and Model Arab League. Through this program, Kennedy has travelled to Qatar and Morocco where she was able to learn culture and policy in the MENA region. Kennedy was also an intern with the House Majority Whip, the Honorable James E. Clyburn. During her time with the congressman, she aided with legislation that advocated for the rural populations of South Carolina. Kennedy intends to pursue a $\mathrm{PhD}$ program in international studies with a focus on the Middle East.

\section{Kaiyla Banks}

Kaiyla Banks is a rising senior at the University of Pennsylvania. She is currently majoring in political science with a concentration in American politics. She is a Mayor's Scholar, a member of Pi Sigma Alpha Political Science Honor Society, and a research

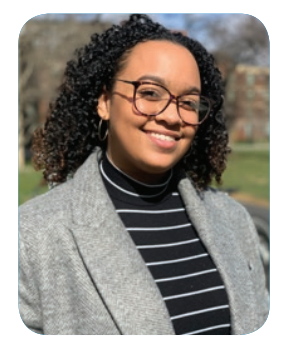

assistant under political scientist and professor Dr. Gillion. She also serves as a journalist for Christian Union Magazine, and as a peer mentor for PennCAP for 10-12 first-generation, low-income students a year. Kaiyla worked as a Fox Fellow for the PRRUCS Collegium Institute in the summer of 2019 and has been recognized twice for academic excellence by the Onyx Senior Society at the University of Pennsylvania. Following her undergraduate studies, Kaiyla is interested in pursuing a $\mathrm{PhD}$ in American politics with a concentration in race and ethnic politics. Her research interests include identity politics and their effects on political behavior, political protests and their efficacy in political action, and race-based voter discrimination in political institutions.

\section{India "Indy" Cousin}

India "Indy" Cousin is a senior at Wake Forest University. She is majoring in political science with minors in philosophy and Spanish. She pursues social justice in Winston-Salem, the nation's largest food desert, serving as the program leader for the Social Justice Residence Community for two years. In this role, she forges formal relationships between community leaders and groups on campus, and conducted an independent study on current food deserts

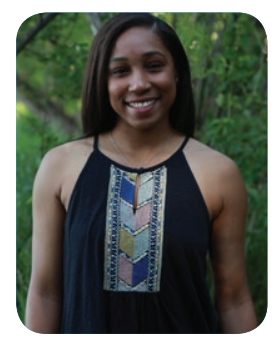
in relation to systematic and institutional discrimination in Winston-Salem. She has participated in the Templeton Business Ethics Case Competition, where she won first place in advocacy of affirmative action for women in a corporate setting. Indy also worked with the United Saints Recovery Project in New Orleans, Louisiana with members of the Wake Forest community. Over Spring Break, she co-directed other volunteers in efforts to rehabilitate areas affected by lasting Hurricane Katrina damage. After graduation, she intends to pursue a $\mathrm{PhD}$ in racial and ethnic studies or law school.

\section{Ana Margarita “Gari” De Ramos}

Ana Margarita "Gari" De Ramos is a student at Clark University studying political science with a concentration in comparative politics. De Ramos is a Clark University Global Scholar, a regular on the Dean's List, and an Advancing Clark Excellence mentor where she mentors multicultural and firstgeneration students. She has completed research under President David Angel about Massachusetts' climate policy and wrote and passed a Climate Emergency Declaration in Worcester, making Worcester

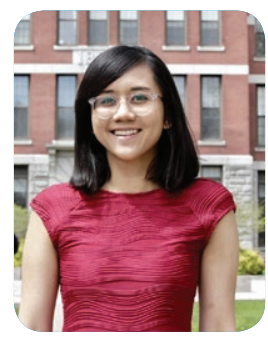
the first municipality in New England to do so at the time. Originally from the Philippines but raised in Hong Kong and New York, her academic interests concern how climate change drives migration. De Ramos is excited to research how current conceptions of borders, the nation, and citizenship may be insufficient in the face of mass climate migration. After graduation, she plans to carry on her career in journalism before pursuing a $\mathrm{PhD}$ in political science. She would like to become a professor to mentor future scholars or do research with think tanks on policy that address climate change and migration.

\section{Luis Delgadillo}

Luis Delgadillo is a first-generation student from the bi-national community of El Paso, Texas and Ciudad Juarez, Chihuahua, Mexico. He is a rising Senior at Cornell University majoring in government and Spanish with a minor in Latin American studies. Delgadillo is passionate about Latin America, immigration issues, and indigenous communities across Latin

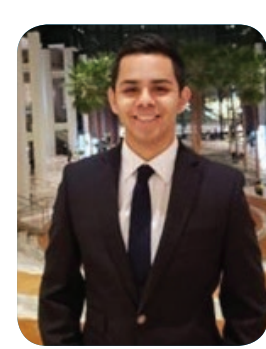
America and the Caribbean. He has founded the University Preparedness Program (UPP) in El Paso, Texas with the endorsement of then Congressman Beto O'Rourke, to increase the number of first-generation, low-income, minority students pursuing 
higher education in the El Paso/Ciudad Juarez area. He is also the president and founder of Humanity on the Hill: The Podcast. His work in collaboration with the International Mayan League and Justice 4 Migrant Women aims to address the violations of human rights on indigenous communities across Central and South America and the Caribbean. After graduation, Luis hopes to travel through Latin America to enact real change through grassroots community works and later pursue a joint JD/PhD degree.

\section{Camille Edwards}

Camille Edwards is a junior at the University of California, Irvine majoring in political science. She is a resident adviser, Pre-Law Society member, and six-time Dean's Honor List recipient. As a current Black Student Union co-chair, Camille is dedicated to her community as an organizer and advocate for marginalized students in addition to her involvement with numerous cultural resource centers on campus.

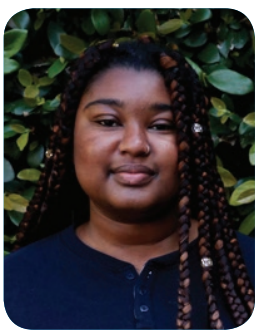
Her research interests include critical race theory, radical political theory, and comparative government structures. Inspired by the variety of lived experiences of black people oppressed by the cisheteropatriarchy, Camille is conducting her undergraduate honors thesis on black feminism as part of the honors program. She plans to stay at UCI for a fifth year to obtain a second degree in sociology. After graduation, Camille will enroll in an interdisciplinary $\mathrm{PhD}$ program to research comparative political theory as well as the relationship between media, resistance movements, and the carceral state.

\section{Triston Ferguson}

Triston Ferguson is a junior at the Univer-

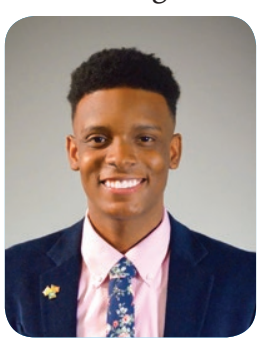
sity of North Texas majoring in political science and minoring in communication studies with a certification in legal studies. He serves as the vice president of the Phi Alpha Delta

Pre-Law fraternity, Academic \& Social Chair of the Delta Epsilon Psi Fraternity Inc., and a member of the UNT Debate
Team. As a President's List recipient, he proves to be a well-rounded student. During the summer of 2018, he worked as an intern within the US House of Representatives. $\mathrm{He}$ is the founder and president of "Unity in Difference," an organization dedicated to building a bridge between underrepresented individuals and their chances of intergenerational mobility. He is particularly interested in expanding his knowledge of political economy and its relation to underrepresented individuals. After graduation, he hopes to enroll in a dual JD/PhD program with concentrations in corporate law and public policy. He wishes to one day develop policy methods and recommendations tailored towards mitigating the inherent effects of institutional barriers.

\section{Jacqueline Figueroa}

Jacqueline Figueroa is a rising senior at Denison University double majoring in political science and anthropology/sociology. She is a Denison-Columbus Alliance Scholarship Recipient, a Phi Society member, and a fellow of the anthropology/ sociology department. Since her sophomore year, she has served on the executive team for Sisters in Dialogue, a program dedicated to building community among women of

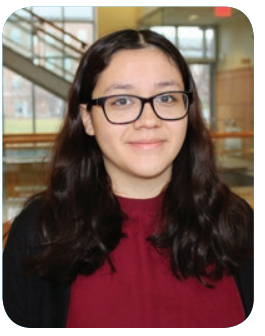
color on Denison's campus. As a child of immigrant parents, she has become deeply interested and passionate about issues around immigration and refugee policy and their effects on conceptions of citizenship. She conducted research through the Denison Young Scholars Program on US asylum policy and how powerful states act hypocritically regarding their supposed obligations towards this vulnerable community. Jacqueline hopes to go to graduate school in political science in order to continue contributing to research in this area, and to translate that research into meaningful and practical contributions to immigrant and refugee communities in the US.

\section{Tylir Fowler}

Tylir Fowler is a rising senior at Temple University double majoring in political science and economics. As a multipletime Dean's List recipient, a member of Pi Sigma Alpha, and a political science honors student, he has excelled academically, and has an interest in researching health

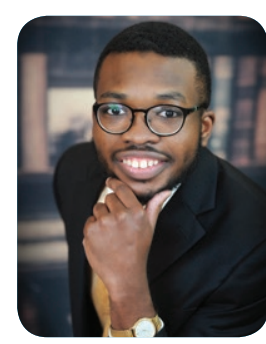

disparities, institutional racism, and economic inequality. Coming from a family with a history of fighting for political justice, Fowler has made it a goal to improve the lives of others. He worked on the 2018 congressional campaign of deputy mayor of labor for the city of Philadelphia, Rich Lazer, and continues to promote voter participation in Delaware County (Delco) through volunteer work with Delco Democrats. Tylir also involves himself with the A. Philip Randolph Institute in order to achieve racial justice in his community. After graduating, Tylir plans to pursue a doctoral degree in political science focusing on the political economy of healthcare. He hopes to bring about change in policy-making and political science discourse by bringing a new perspective on modern issues.

\section{Mariana Galvez Seminario}

Mariana Galvez Seminario is a third-year student at the University of Colorado, Boulder double majoring in sociology and women \& gender studies. They are interested in reproductive justice and the issues that it encompasses such as immigration justice, trans and queer liberation, housing justice, and food security. They work with the Colorado Organization for Latina Opportunity and Reproductive Rights (COLOR), and they were their policy intern for the legislative session of 2019. They are doing

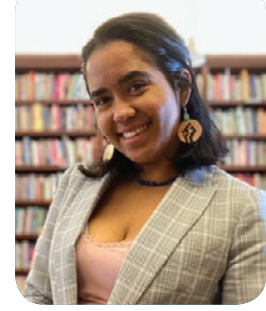
research on the Latina/o/x contributions to intersectionality and the theoretical and empirical considerations of the " $\mathrm{x}$ " in Latinx and womxn (etc.) with their mentor. They were scheduled to present the paper on " $x$ " at the (now cancelled) WPSA conference in April 2020. They are also doing their own research on the Latina/ $\mathrm{x}$ contributions to reproductive justice at its foundation and in contemporary moments, as well how one can queer reproductive justice. Mariana is excited to research and write about reproductive justice through a political science lens and believes it will be useful in the field and the movement. 


\section{Jada Grisson}

Jada Grisson is a rising senior at The College of New Jersey, double majoring in political science and African American studies. A 2019 New Jersey Black Caucus Intern, Jada spent the summer assisting with legislation on the black maternal mortal-

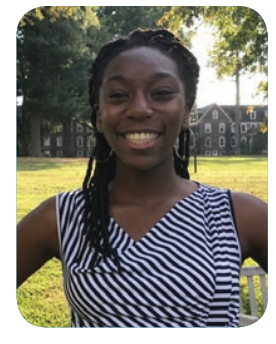
ity crisis. Jada has also spent the past two years working with Planned Parenthood Generation Action of New Jersey, the collegiate advocacy level of Planned Parenthood. She is currently an intern with Representative Watson Coleman (D-NJ) of district 12. Passionate about reproductive justice and black feminist praxis, Jada hopes to pursue a career in Civil Rights law and human rights.

\section{Aryssa Harris}

Aryssa Harris is a rising senior at Beloit College majoring in political science and sociology with a minor in Spanish. As a head resident assistant, a Ronald E. McNair Scholar, a two-year president of Black Students United, and a student representative serving on Beloit College's

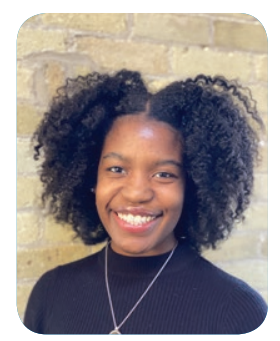
Board of Trustees, she shows that she takes initiative and has a passion for leading. As a Ronald E. McNair Scholar, Aryssa has conducted research with Dr. Rongal Watson at Beloit College on the disparate impact of mass incarceration on black males in relation to the War on Drugs. Aryssa's research interests include comparative politics, public policy, and racial and ethnic politics. After graduation, Aryssa plans to pursue a dual degree in JD/PhD in political science and would like to use her political science knowledge to represent underrepresented individuals in legal settings. Aryssa also plans on running for political office at some point in her career.

\section{Natalie Jones}

Natalie Jones is a first-generation, rising senior at Iowa State University majoring in political science and history. She was born in Wisconsin and is a proud member of the Bad River Band of Lake Superior Chippewa Indian tribe. Natalie is a three- time awarded Cobell Indian Scholar and an academic adviser to her sisters in Delta Zeta sorority. She is passionate about American Indian rights, access to education, and healthcare. Natalie has done political campaign research for two years alongside her university's faculty through the National Science Foundation. She has also volunteered in various presidential campaigns leading to the Iowa caucus and hopes to continue to spread awareness to more high profile

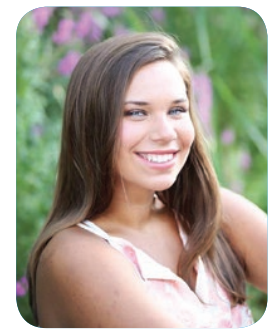
candidates about these issues. Natalie plans to use her interest in politics to help underrepresented communities gain support through research and her interest in the law. After graduation, she plans to enter a $\mathrm{PhD} / \mathrm{JD}$ program to fulfill her dream to help others.

\section{Alesha Lewis}

Alesha Lewis is a junior at Southwestern University majoring in political science and psychology. She works as a research assis-

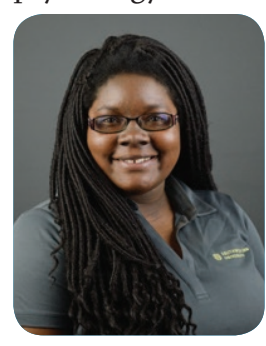
tant for the political science department studying the role of place-based identity in political behavior. She is a recipient of the Bishop Ernest T. Dixon Scholar Award, was named on the Dean's List and will be graduating with "paideia with distinction" next spring after completing a series of academic experiences, engagement with the community, and teaching part of a class to her peers on the interconnectedness of academic disciplines. Her research interests include voting behavior, political participation and civil discourse. After graduation, she plans to pursue a doctorate in political science with a concentration in political psychology and become a prominent research analyst.

\section{Uchenna Nwodim}

Uchenna Nwodim is a rising senior studying political science and African American studies at Pennsylvania State's Schreyer Honors College. Born and raised in Baltimore, Maryland, she was exposed to inequalities that informed her choice of study. On campus, she is the treasurer of the first-ever League of Women's Voters on a college campus. She routinely regis- ters students to vote and works to educate students on the candidates who are running in federal, state, and local elections. She is also a member of the MLK Committee, which puts on events that educate the community on how social justice and diversity can create an impact on our society. She is an undergraduate poll coder for

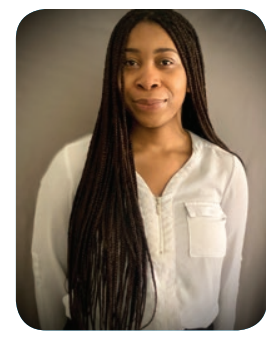
the McCourtney Institute for Democracy, where she analyzes how Americans feel about the current political climate. Additionally, she conducted research with the Rock Ethics Institute, where she designed and conducted an experiment that examined social disparities in criminal justice from a psychological perspective. After graduation, she plans on pursuing a $\mathrm{PhD}$ in political science.

\section{Nelson Quezada}

Nelson Quezada is a first-generation junior at Stetson University majoring in political science and English with a minor in history and a certificate in community engagement. Nelson is a Bonner Scholar and serves as

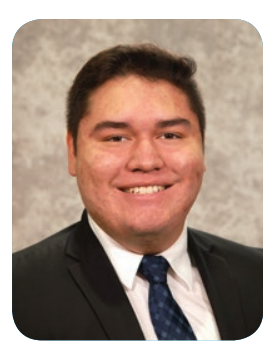
the community outreach intern for the Community Education Project, a higher education in prison program. $\mathrm{He}$ is a member of the Phi Sigma Alpha and Sigma Tau Delta honor societies. Previously, he served as president of College Democrats, a senator in Stetson's Student Government Association, and co-chair of Stetson University's Floyd M. Riddick Model Senate. Nelson is interested in political psychology and political behavior with a focus on empowering historically marginalized communities. Winning a highly competitive institutional grant, Nelson took on a summer research project examining the combined effects of issue framing and identity priming on attitudes towards the Green New Deal. He extended the findings of that project for his senior research and was scheduled to present his paper at the (now cancelled) Florida Political Science Association in April 2020. After graduation, Nelson plans to pursue a $\mathrm{PhD}$ in political science. 


\section{Jessica "Jess" Ruiz}

Jessica "Jess" Ruiz is a first-generation, third-year student at Cal State Bakersfield majoring in political science with an emphasis on American government and

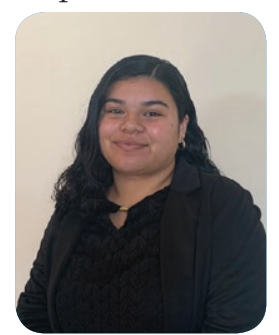
global affairs. They are a member of the Model United Nations and Club GEN (Gender Equality Now). Ruiz is working on a research projected focused on women delegates and their role in the United Nations which they were scheduled to present at the (now cancelled) Western Political Science Association. They are also the vice president of United Now for Immigrant Rights and participate in other organizations within their community that focus on shutting down and stopping the expansion of immigrant detention centers. After graduation, they plan on pursuing a $\mathrm{PhD}$ in political science to become a professor. Their research interests are Latin American politics, women in politics, and race and ethnic politics.

\section{Michaela Shelton}

Michaela Shelton is a student at Pomona College majoring in politics with a concentration in comparative politics. Michaela is a student activist who has done work in youth civic engagement. In the fall of 2018 , she co-lead a team of 30 first year volunteers

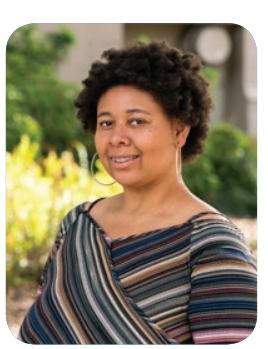
at Pomona College to get-out-the-vote and helped revive the school's partnership with TurboVote. The team's efforts resulted in a $23 \%$ increase in voter participation on Pomona's campus, earning the school a silver medal with the ALL IN Campus Democracy challenge. Michaela's interest in advocacy spans across voting rights, criminal justice reform, and civil rights. After college, she hopes to enter a career of public service by pursuing a JD/PhD program in law and political science.

\section{Nina Small}

Nina Small is a junior at Hampton University majoring in political science with a minor in Spanish. At Hampton, she is a four-time Dean's List recipient. Nina's commitment to serving her community is exhibited by being a part of Sisters Inspiring Sisters, a mentoring program for young girls in the Hampton Roads area, and being a part of the Hampton University Student Recruitment Team. She currently interns as a teacher's assistant, primarily for assistant professor Dr. Mohammed B. Sillah. Nina also was a summer intern at Allen Brothers PLLC located in Detroit, Michigan. She is a recipient of the Spirit of Detroit award, Hampton University room and board scholarship, Hampton University Detroit Alumni

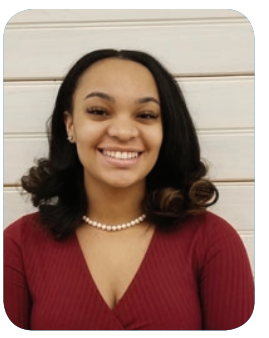
Scholarship, and the Plymouth United Church of Christ Pruitt scholarship. After graduation, Nina plans to pursue a $\mathrm{PhD}$ in environmental policy with a concentration in environmental racism. She hopes to work in a capacity to bring about change within the minority communities, to correct the disparities still lingering from the past.

\section{Maya Thornton}

Maya Thornton is a rising senior at Grambling State University majoring in political science. Thornton has served as the junior class associate justice, a student ambassador, and as the Student Networking Team

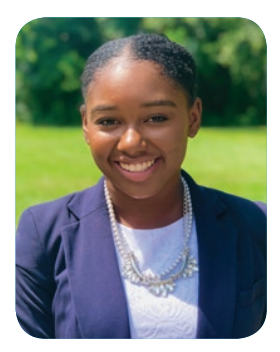
Coordinator's Assistant for the National Society of Leadership and Success. She is a member of the Earl Lester Cole Honors college and has maintained a spot on the President's List during her time at Grambling State University. She is also an English tutor for the state of Louisiana through the Gear Up program. During the fall semester of 2019, Ms. Thornton was inducted into the Alpha Tau Chapter of Phi Beta Lambda Business Fraternity, Inc. She is passionate about studying race and gender politics and hopes to encourage change in the conditions of black Americans through her research. After completing her undergraduate degree in political science, she plans to pursue a PhD that explores the intersectionality of gender and racial politics. 